\title{
Assessment of Heavy Metal Contamination in Sea Bed Sediment of the Bight of Bonny, Southern Atlantic Coast of Nigeria Using Index Model Analysis
}

\author{
Justin Nnaemeka Okorondu1 ${ }^{*}$, Elechi Owhoeke ${ }^{2}$, Bridget Edewede Diagi1, \\ Joseph Ikechukwu Nwachukwu' ${ }^{1}$, Lucy C. Izunobi ${ }^{1}$ \\ ${ }^{1}$ Department of Environmental Management, Federal University of Technology, Owerri, Nigeria \\ ${ }^{2}$ Department of Industrial Chemistry/Petrochemical Technology, University of Port Harcourt, Port Harcourt, Nigeria \\ Email: *justin.okorondu@gmail.com
}

How to cite this paper: Okorondu, J. N., Owhoeke, E., Diagi, B. E., Nwachukwu, J. I., \& Izunobi, L. C. (2021). Assessment of Heavy Metal Contamination in Sea Bed Sediment of the Bight of Bonny, Southern Atlantic Coast of Nigeria Using Index Model Analysis. Journal of Geoscience and Environment Protection, 9, 286-298. https://doi.org/10.4236/gep.2021.912017

Received: October 22, 2021

Accepted: December 28, 2021

Published: December 31, 2021

Copyright $\odot 2021$ by author(s) and Scientific Research Publishing Inc. This work is licensed under the Creative Commons Attribution International License (CC BY 4.0).

http://creativecommons.org/licenses/by/4.0/

\begin{abstract}
The heavy metal contamination status of Bight of Bonny sea bed sediment was investigated. Sediment samples were collected from eleven locations grouped into three stations. The samples were analyzed to determine the heavy metals $(\mathrm{Fe}$, $\mathrm{Pb}, \mathrm{Ni}, \mathrm{Zn}, \mathrm{Mn}, \mathrm{Co}, \mathrm{Cd}, \mathrm{Cu}, \mathrm{Cr}$ ) concentration using atomic absorption spectrophotometer. Index model analyses, such as geo-accumulation index (I-geo), Enrichment factor (EF), and Pollution load index (PLI) were used for pollution assessment of sea bed sediment. The most predominant heavy metals in the upstream sediment were Fe; $13.57 \pm 1.838 \mathrm{mg} / \mathrm{kg}$, cobalt; $7.987 \pm 3.550$ $\mathrm{mg} / \mathrm{kg}$, and $\mathrm{Ni} ; 1.020 \pm 0.802 \mathrm{mg} / \mathrm{kg}$, midstream sediment were Fe; $8.554 \pm$ $3.010 \mathrm{mg} / \mathrm{kg}$, Co; $8.520 \pm 4.00 \mathrm{mg} / \mathrm{kg}$, and Ni; $1.140 \pm 0.879 \mathrm{mg} / \mathrm{kg}$, while the downstream sediment result had Fe; $11.12 \pm 3.825 \mathrm{mg} / \mathrm{kg}$, Co; $7.275 \pm 1.700$ $\mathrm{mg} / \mathrm{kg}$, and $\mathrm{Cd} ; 1.025 \pm 0.159 / \mathrm{kg}$. The I-geo results indicate that $\mathrm{Cu}, \mathrm{Mn}, \mathrm{Pb}$, $\mathrm{Cr}, \mathrm{Fe}, \mathrm{Zn}, \mathrm{Ni}$, and $\mathrm{Co}$ were in their background concentrations while $\mathrm{Cd}$ had I-geo $>3$ which implies a moderately or heavily polluted environment. The EF indicates metal enrichment from anthropogenic sources for $\mathrm{Co}, \mathrm{Ni}, \mathrm{Pb}, \mathrm{Cd}$, $\mathrm{Cu}$, and $\mathrm{Cr}$ while $\mathrm{Fe}$ and $\mathrm{Mn}$ predicate biogenic origin. The PLI of the heavy metals in the three sample stations of sea bed sediment was found to be generally low $(<1)$. The Enrichment Factor and geo-accumulation index strongly suggest the Bight of Bonny sea bed sediment contamination by $\mathrm{Cd}$ from anthropogenic sources.
\end{abstract}

\section{Keywords}

Pollution Assessment, Heavy Metal, Sediment, Enrichment Factor, 
Geo-Accumulation Index, Pollution Load Index

\section{Introduction}

Metal pollution is a serious issue in the aquatic ecosystem because of its toxicity and ability to accumulate in the biota (Ghrefat et al., 2011). Sediments form a critical part of the aquatic ecosystem; made up of fine, medium, and coarse grain minerals and organic particles found at the bottom of surface water bodies (Ogbeibu et al., 2014). Heavy metals come from both natural and anthropogenic sources and are one of the most common environmental pollutants in river sediment. Sediment naturally acts as an excellent trap and final sink for heavy metals in the aquatic ecosystem. It can as well release contaminants to the water column by various processes of remobilization under variable conditions (Marchand et al., 2006; Davies \& Abowei, 2009).

Pollution of littoral waters of the Niger Delta region of Nigeria has in recent times received much attention as a result of a high degree of environmental degradation and aquatic perturbation posed by petroleum exploration activities (Benson et al., 2007). The Bight of Bonny extends its tributaries to Qua Iboe River, which has been reported as a recipient environment for industrial effluents especially from the oil and gas industries and agricultural run-offs (Eni et al., 2021). Sediment as an essential component in an aquatic ecosystem serves as a sink and also a source of heavy metal (Marchand et al., 2006; Davies \& Abowei 2009; Abdullah et al., 2007). Heavy metals most often quickly settle in the sediment upon deposition in surface waters and are much more concentrated in the sediment than in the water body of aquatic ecosystem (Shyleshchandran \& Ramasamy, 2018; Liu et al., 2018). This is due to their chemical properties having atomic weights between 63.546 and 200.590 and specific gravity that is 5 times greater than that of water (Andem et al., 2015). More so, when the physicochemical or hydrological conditions change, heavy metals in the sediment may desorb or resuspend to cause secondary pollution in the water body. The presence of heavy metals is of great concern in terms of pollution of the aquatic ecosystem due to their persistence, environmental toxicity, bioaccumulation, amongst others (Zhang et al., 2014; Jordanova et.al, 2018), which can result in negative effects on the ecological health of aquatic animal species and decline in their population.

The use of index model analysis (EF, I-geo, PLI) has been a veritable tool in the assessment of heavy metals in river sediment. This is because each sediment layer in the river has been formed as a result of a continued sedimentation process; hence, investigating the anthropogenic impact on the sediment is most probable (Fernandes \& Nayak, 2012). EF and I-geo indexes are known to distinguish between the sediment being enriched by anthropogenic or natural input (Praveena et al., 2008). The I-geo allows the practical determination of contami- 
nation for the examined sediment of organic and inorganic substances by comparing present concentrations with pre-industrial sediment layers (Loska et al., 1997; Ji et al., 2008). Consequently, the use of index model analysis enables us to gain an integrated picture of the metal contamination in the sediment, therefore, determining either the sediment presence as natural phenomena, anthropogenic activities, or a combination of both (Nur et al., 2013).

The Southern Atlantic coast is of economic importance to the coastal communities in the Niger Delta region of Nigeria; providing more than 17 species of various types of fish (Ekpo et al., 2014). The fishing business has provided a huge income to the fishing communities living within the coastal areas of the Niger Delta region. It has become imperative to assess the sea bed sediment quality of Bight of Bonny because heavy metal toxicity in the food chain could have a debilitating effect on human health. The study area covers a horizontal stretch of a crude oil pipeline that delivers crude to Qua Iboe Terminal (QIT) from an offshore oil installation which supports about $50 \%-60 \%$ of Idoho, Usari, Asabo, Ekpe, Inim, and Etim Exxonmobil oil productions (Adewole, 2018). The impact on sea bed sediment from industrial discharges, oil spillage within the stretch of this pipeline, and other poor waste management practices in the coastal areas as reported in academic literature (Eni et al., 2021; Oze et al., 2005; Apkan, 1991) has necessitated this research work. This study reports the heavy metals concentration in the Bight of Bonny river bed sediment to evaluate the pollution status using pollution index model analysis.

\section{Materials and Method}

\subsection{Study Area}

The Bight of Bonny is situated on the Southern Atlantic coast of Nigeria $\left(4^{\circ} 15^{\prime} \mathrm{N}-4^{\circ} 35^{\prime} \mathrm{N} ; 7^{\circ} 30^{\prime} \mathrm{E}-8^{\circ} 25^{\prime} \mathrm{E}\right)$. This coastal aquatic system is about $100 \mathrm{~km}$ long and more than $30 \mathrm{~km}$ wide and constitutes the eastern flank of the Niger Delta (Ntekim et al., 1993), traversing the shorelines of Akwa Ibom, Cross River, and the Rivers States of Nigeria. The entire ecosystem is made up of an extensive network of rivers, estuaries, creeks, and tributaries which together form a significant commercial hydrographic feature within the region. The study area is generally humid and characterized by double maxima rainfall. The area is also noted for its humid tropical climate with total annual precipitation of $2000 \mathrm{~mm}$ to 4000 $\mathrm{mm}$, it has a uniform temperature regime with an annual range between $25^{\circ} \mathrm{C}$ to $28^{\circ} \mathrm{C}$ (Iloeje, 1991; Esu \& Amah, 1999). The area covers a horizontal stretch of a crude oil pipeline that delivers crude to Qua Iboe Terminal (QIT) from an offshore oil installation which supports about 50\% - 60\% of Idoho, Usari, Asabo, Ekpe, Inim, and Etim Exxonmobil oil productions (Adewole, 2018). The study area is exposed to significant anthropogenic inputs such as crude oil spillage, untreated sewage, and industrial wastewaters. Several other smaller fluvial and domestic effluents are also disposed of in the shallow marginal estuarine reaches and creeks (Benson et al., 2007). 


\subsection{Sediment Sampling and Laboratory Analysis}

The field sampling design consists of sampling points with transects oriented toward the South, East, and West directions covering a distance of about $14 \mathrm{~km}$ in the southeast direction. The control sample was collected about $3.5 \mathrm{~km}$ from the offshore crude oil production facilities. Eleven sediment samples were collected around some offshore crude oil facilities. The sample stations were grouped into three, namely; SD1, SD2, SD3 as Station 1; SD4 and SD5 as station 2, and SD6, SD7, SD8, as station 3 and SD9, SD10 as Station 4 for the downstream. The control sample was coded SD CNTRL as shown in Figure 1. A $320 \mathrm{~kg}$ Day Grab was used for the sediment sampling. Grab-bites were obtained and sub-sampled at each station. The day grab was set in position and deployed into the seawater using a winch and A-frame attached to the vessel. The grab was attached to the winch with wireline and was lowered to the sea bottom and retrieved immediately afterward. The content of the grab was sub-sampled for heavy metals into a polyethylene bag following the standard procedure described in American Public Health Association (APHA) (APHA, 1998).

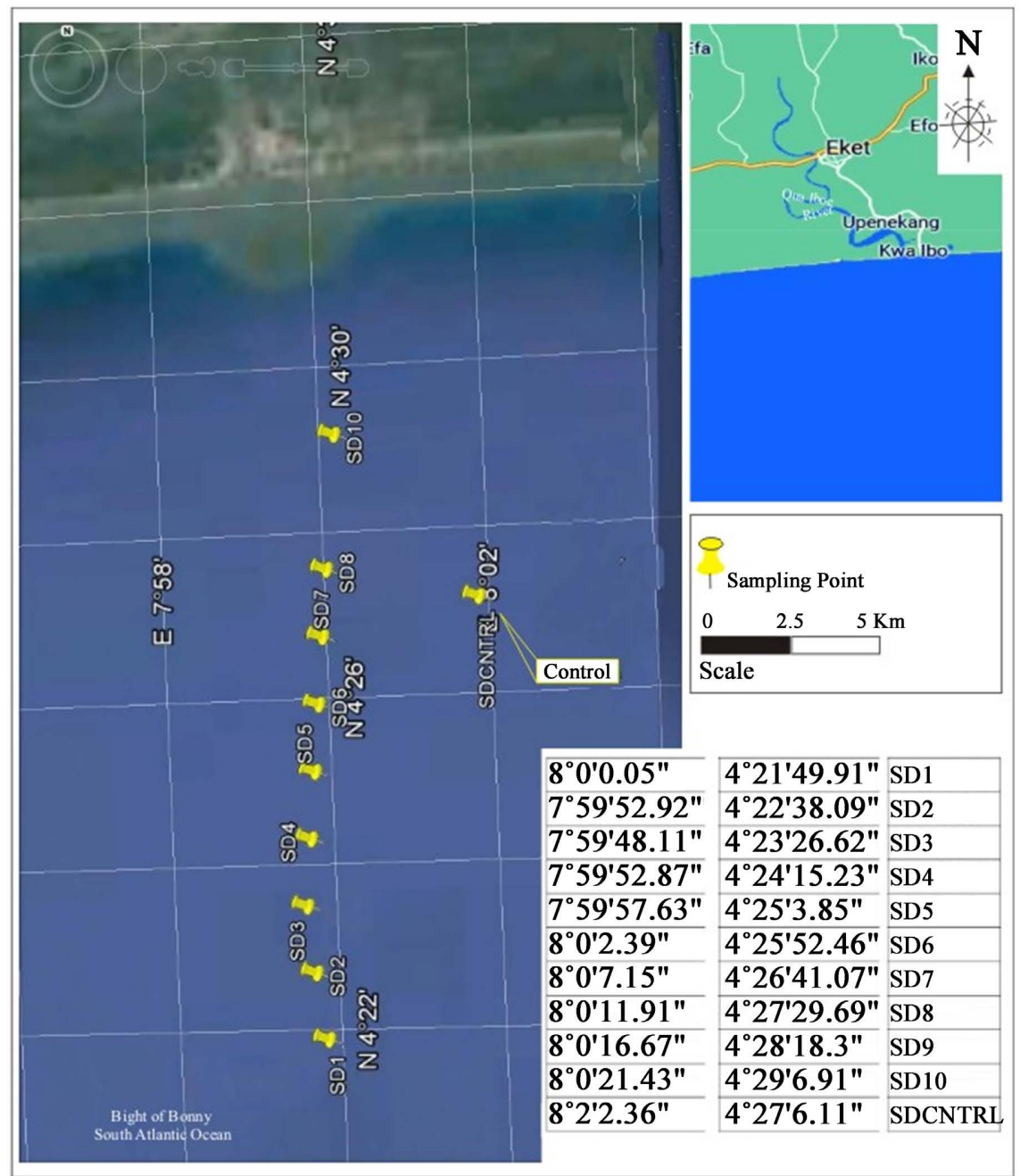

Figure 1. Study area showing sampling locations. 


\section{Sample pre-treatment and analysis}

The sediment samples were air-dried and ground to a fine powder in a mortar. The powdered sediment was then sieved through a $0.5 \mathrm{~mm}$ sieve to remove coarse materials. $1 \mathrm{~g}$ of the sediment powder was digested using a 1:5:1 mixture of perchloric acid, concentrated $\mathrm{HNO}_{3}$, and concentrated $\mathrm{H}_{2} \mathrm{SO}_{4}$ in a fume chamber at $80^{\circ} \mathrm{C}$ until a colorless liquid was obtained (Oguzie, 2003). The sample digest was diluted to $50 \mathrm{ml}$ and analyzed for the listed heavy metals $(\mathrm{Fe}, \mathrm{Pb}$, $\mathrm{Ni}, \mathrm{Zn}, \mathrm{Mn}, \mathrm{Co}, \mathrm{Cd}, \mathrm{Cu}$, and $\mathrm{Cr}$ ) at their various resonance frequency using Atomic Absorption Spectrophotometer (Varian SpectrAA 220).

\subsection{Contamination Level Analysis}

The pollution status of the study area was assessed using the various pollution assessment indices, namely the contamination factor (CF), geo-accumulation (Igeo), enrichment factor (EF), and the pollution load index (PLI).

\section{Contamination Factor (CF)}

$\mathrm{CF}$ is defined as the ratio of metal content in the sample to the background value of the same metal. It is given by the following:

$$
\mathrm{CF}=\mathrm{C} \text { (metal) Sample/C (metal) background value }
$$

where $\mathrm{C}$ (metal) is the concentration of metal analyzed from sampled soil and where C (metal) background value is the geochemical background value (or concentration) of that metal.

The values of the contamination factor are characterized as follows: $(7<1-$ low contamination factor indicating low contamination of the sediment with the examined "r substance, $1 \leq \mathrm{Cf}<\mathrm{C} \sim \leq \mathrm{C} \sim$ very high contamination factor. Contamination factor is used to evaluate the pollution of the environment by single substances. The sum of contamination factors expresses the value of contamination degree which describes the contamination of the environment by all examined substances. The degree of contamination defines the quality of the environment in the following way: $\mathrm{C}, \mathrm{t}<8$ low degrees of contamination, $8 \leq \mathrm{C}<\mathrm{z}<$ 16 moderate degrees of contamination, $16 \leq \mathrm{C}, \leq 32$ considerable degrees of contamination, $32 \leq$ C, very high degree of contamination (Loska et al., 1997).

\section{Geo-accumulation index (Igeo)}

The heavy metals (HMs) contamination level based on baseline concentrations data were estimated by the model or method suggested by Muller (1969), which is called the geo-accumulation index (Igeo). This technique measures the elemental pollution in terms of seven (0 to 6) enrichment classes ranging from background level to very heavily polluted, as follows:

$$
\text { Igeo }=\log 2
$$

$\mathrm{Cn}$ is HMs concentration in the sample, $\mathrm{Bn}$ is the geochemical background value in the average shale of the element (Turekian \& Wedepohl, 1961), the shale value was 1.5 of the background matrix correction in factor due to lithogenic consequences (Table 1). 
Table 1. Contamination level index for the various areas of study.

\begin{tabular}{ccl}
\hline Class & Value & \multicolumn{1}{c}{ Soil quality level } \\
\hline 0 & Igeo $<0$ & Uncontaminated \\
1 & $0<$ Igeo $<1$ & Uncontaminated to moderately \\
2 & $1<$ Igeo $<2$ & Moderately Contaminated \\
3 & $2<$ Igeo $<3$ & Moderately to heavily contaminated \\
4 & $3<$ Igeo $<4$ & Heavily Contaminated \\
5 & $4<$ Igeo $<5$ & Heavily contaminated to Extremely Contaminated \\
6 & Igeo $>5$ & Extremely Contaminated \\
\hline
\end{tabular}

\section{Enrichment Factor}

It is a measure of the metallic concentration to the reference metal (iron) in the sample compared to the world average shale values, as shown below (Reimann \& De Caritat, 2004).

$$
\mathrm{EF}=(\mathrm{M} / \mathrm{Fe}) \text { sample } /(\mathrm{M} / \mathrm{Fe}) \text { background }
$$

$\mathrm{M}=$ metal ion concentration in both the sample and background while $\mathrm{Fe}=$ iron concentration in both the sample and the background. Zhang \& Liu (2002) stated that EF values from $1 / 2$ to 1.5 show the metal is of biogenic or natural processes, while values more than 1.5 are of anthropogenic or man-made sources. There are five contamination categories according to Sutherland (2000), where $\mathrm{EF}<2$ represents the depletion of mineral enrichment; $2 \leq \mathrm{EF}<5$, moderate enrichment; $5 \leq \mathrm{EF}<20$, significant enrichment; $20 \leq \mathrm{EF}<40$, very high enrichment; EF $>40$, extremely high enrichment

\section{Pollution Load Index}

However, the sediment/soil quality is assessed based on Tomlinson's pollution load index (PLI), an integrated approach proposed by Tomlinson et al. (1980). The PLI is calculated according to equation 4, and is defined as the nth root of the multiplications of the contamination factor of each metal:

$$
\mathrm{PLI}=\left(\sum \mathrm{CF} 1 \times \mathrm{CF} 2 \times \mathrm{CF} 3 \times \cdots \times \mathrm{CFn}\right)^{1 / \mathrm{n}}
$$

where CF is the contamination factor; Cmetal is metal concentration in the sediment.

The PLI value of $>1$ is polluted while $>1$ indicates no pollution (Harikumar, 2009).

\section{Results and Discussion}

The results show a very low concentration of $\mathrm{Cr}$ and $\mathrm{Cu}$ in most of the sample stations in the study area as shown in Tables 2-4. The concentration of $\mathrm{Cu}$ was below equipment detection limit (BDL) in most sample stations as shown in Tables 2-4, except Upstream Station $2(1.74 \mathrm{mg} / \mathrm{kg})$, Downstream Station 1 $(0.64 \mathrm{mg} / \mathrm{kg})$ and Downstream Station $2(0.24 \mathrm{mg} / \mathrm{kg})$. A Cr concentration of $2.560 \mathrm{mg} / \mathrm{kg}$ was recorded only in Upstream Station 2 as shown in Table 2, 
whereas, other sampling locations had values below the equipment detection limit. The mean concentration of Fe ranged from $8.55 \pm 3.011$ in the mid-stream to $13.57 \pm 1.838$ downstream of the study area. $\mathrm{Zn}$ had mean concentration values from $0.036 \pm 0.008$ (upstream) to $0.068 \pm 0.012$ (mid-stream). Other metals such as $\mathrm{Mn}, \mathrm{Co}, \mathrm{Pb}, \mathrm{Ni}$, and $\mathrm{Cd}$ had mean values $-0.110 \pm 0.081$ to $0.134 \pm$ $0.095,7.225 \pm 1.700$ to $8.520 \pm 4.00,0.417 \pm 0.133$ to $0.472 \pm 0.261,0.189 \pm 0.321$ to $1.140 \pm 0.879,0.853 \pm 0.251$ to $1.025 \pm 0.159$ respectively as shown in Tables $2-4$. This result indicated that the level of iron was higher in the upstream than the downstream and the midstream was the least, this could be attributed to the level of human activities within the upstream, this zone of the sea is closest to the coastline, meaning it receives more of the contaminant coming from the soil than the other two zones. Apart from iron, the other heavy metals were inconsistent in the amount found in the three zones, this could be as a result of the river flow direction and also a tidal movement which could have deposited more contaminant at one zone than the rest of the zone.

The high concentration of Fe over the other metals as shown in Tables 2-4 was similar to results reported by (Iwuoha, et al., 2012; Uwah et al., 2013; Ogbeibu et al., 2014). The low concentration of $\mathrm{Cr}$ and $\mathrm{Cu}$ was consistent with results from other studies (Eni et al., 2012; Andem et al., 2015; Uwah et al., 2013; Ogbeibu et al., 2014; Iwuoha et al., 2012). The mean $\mathrm{Cd}$ and $\mathrm{Pb}$ results were higher than previous studies on the Qua Iboe river estuary as reported by (Uwah et al., 2013; Eni et al., 2021). The high level of iron in each of the three zones and the study area is a signal of activities that release such within the area of study. The high iron level could be from barges transporting oil, an oil pipeline that traverses the sea. The presence of cobalt and nickel was high too which may be due to numerous anthropogenic activities going within the study area. The occurrence of these heavy metals may have numerous effects on living and non-living organisms within the study zone.

The I-geo grades for the study area sediment vary from 0 (unpolluted for most

Table 2. Levels of heavy metals $(\mathrm{mg} / \mathrm{kg})$ in sediment upstream of bight of Bonny.

\begin{tabular}{cccccc}
\hline Parameter & Station 1 & Station 2 & Station 3 & Mean & control \\
\hline Iron & 12.64 & 16.14 & 11.94 & $13.57 \pm 1.838$ & 4.673 \\
Zinc & 0.068 & 0.067 & 0.066 & $0.067 \pm 0.001$ & 0.021 \\
Manganese & BDL & 0.207 & 0.195 & $0.134 \pm 0.095$ & BDL \\
Cobalt & 10.16 & 10.82 & 2.980 & $7.987 \pm 3.550$ & 5.432 \\
Lead & 0.840 & 0.315 & 0.260 & $0.472 \pm 0.261$ & 0.270 \\
Nickel & 1.100 & 1.960 & BDL & $1.020 \pm 0.802$ & BDL \\
Copper & BDL & 1.740 & BDL & $0.580 \pm 0.820$ & BDL \\
Chromium & BDL & 2.560 & BDL & $0.853 \pm 1.207$ & BDL \\
Cadmium & 1.000 & 1.060 & 0.500 & $0.853 \pm 0.251$ & 0.080 \\
\hline
\end{tabular}


Table 3. Levels of heavy metals $(\mathrm{mg} / \mathrm{kg}$ ) in the sediment of mid-stream of bight of Bonny.

\begin{tabular}{cccccc}
\hline Parameter & Station 1 & Station 2 & Station 3 & Mean & control \\
\hline Iron & 4.839 & 8.610 & 12.21 & $8.554 \pm 3.011$ & 4.673 \\
Zinc & 0.055 & 0.084 & 0.066 & $0.068 \pm 0.012$ & 0.021 \\
manganese & 0.181 & 0.161 & $\mathrm{BDL}$ & $0.110 \pm 0.081$ & $\mathrm{BDL}$ \\
Cobalt & 2.860 & 11.50 & 11.20 & $8.520 \pm 4.000$ & 5.432 \\
Lead & 0.230 & 0.530 & 0.490 & $0.417 \pm 0.133$ & 0.270 \\
Nickel & $\mathrm{BDL}$ & 2.140 & 1.280 & $1.140 \pm 0.879$ & $\mathrm{BDL}$ \\
Copper & $\mathrm{BDL}$ & 0.240 & $\mathrm{BDL}$ & $0.080 \pm 0.113$ & $\mathrm{BDL}$ \\
Chromium & $\mathrm{BDL}$ & $\mathrm{BDL}$ & $\mathrm{BDL}$ & $\mathrm{BDL}$ & $\mathrm{BDL}$ \\
Cadmium & 0.500 & 1.140 & 1.100 & $0.913 \pm 0.292$ & 0.080 \\
\hline
\end{tabular}

Table 4. Levels of heavy metals $(\mathrm{mg} / \mathrm{kg})$ in the sediment downstream of bight of Bonny.

\begin{tabular}{ccccccc}
\hline Parameter & Station 1 & Station 2 & Station 3 & Station 4 & Mean & control \\
\hline Iron & 12.93 & 14.82 & 12.01 & 4.736 & $11.12 \pm 3.825$ & 4.673 \\
Zinc & 0.049 & 0.028 & 0.035 & 0.034 & $0.036 \pm 0.008$ & 0.021 \\
manganese & 0.163 & 0.175 & $\mathrm{BDL}$ & 0.164 & $0.125 \pm 0.073$ & $\mathrm{BDL}$ \\
Cobalt & 9.880 & 7.540 & 5.780 & 5.700 & $7.225 \pm 1.700$ & 5.432 \\
Lead & 0.550 & 0.410 & 0.440 & 0.350 & $0.437 \pm 0.073$ & 0.270 \\
Nickel & 0.760 & 0.680 & $\mathrm{BDL}$ & $\mathrm{BDL}$ & $0.189 \pm 0.321$ & $\mathrm{BDL}$ \\
Copper & 0.640 & $\mathrm{BDL}$ & $\mathrm{BDL}$ & $\mathrm{BDL}$ & $0.160 \pm 0.277$ & $\mathrm{BDL}$ \\
Chromium & $\mathrm{BDL}$ & $\mathrm{BDL}$ & $\mathrm{BDL}$ & $\mathrm{BDL}$ & $\mathrm{BDL}$ & $\mathrm{BDL}$ \\
Cadmium & 1.220 & 0.780 & 1.020 & 1.080 & $1.025 \pm 0.159$ & 0.080 \\
\hline
\end{tabular}

of the metals) to 3 (moderately or heavily polluted for $\mathrm{Cd}$ ). The I-geo results as shown in Table 5 practically show that $\mathrm{Cu}, \mathrm{Mn}, \mathrm{Pb}, \mathrm{Cr}, \mathrm{Fe}, \mathrm{Zn}, \mathrm{Ni}$, and $\mathrm{Co}$ are in grade 0 , which implies that the study area sediment is in background concentration for these metals. However, an I-geo grade of 3 was recorded for Cd across all sample stations as shown in Figure 2 which suggests a moderately or heavily polluted environment concerning $\mathrm{Cd}$. The I-geo grade of 0 for most of the metals suggests background concentrations (as shown in Table 1) for $\mathrm{Cu}, \mathrm{Mn}, \mathrm{Pb}$, $\mathrm{Cr}, \mathrm{Fe}, \mathrm{Zn}, \mathrm{Ni}$, and $\mathrm{Co}$ in the study area and these elements remain unchanged by anthropogenic activities (especially crude oil exploration) within the study area.

The pollution Load Index (PLI) (calculated using the result of CFs as shown in Table 6) of heavy metals in the in the upstream, midstream and downstream of Bight of Bonny sea bed sediment as shown in Table 7 was found to be generally low $(<1)$. This suggests non-contamination of Bight of Bonny sea bed sediment (study area) by the predominantly selected heavy metals. The PLI partly 
Table 5. Geo-accumulation index from the study area.

\begin{tabular}{cccc}
\hline Parameter & Up Qua I. & Mid Qua I. & Down Qua I. \\
\hline Iron & -12.36 & -13.02 & -13.02 \\
Zinc & -11.05 & -11.02 & -11.97 \\
Manganese & -13.29 & -13.45 & -13.30 \\
Cobalt & -1.756 & -1.666 & -1.905 \\
Lead & -5.993 & -6.169 & -6.099 \\
Nickel & -6.644 & -6.480 & -9.118 \\
Copper & -6.861 & -9.723 & -8.721 \\
Chromium & -7.310 & - & - \\
Cadmium & 2.508 & 1.021 & 1.188 \\
\hline
\end{tabular}

Table 6. Contamination factor from the mean of the study area.

\begin{tabular}{ccccc}
\hline Parameter & Up Qua I. & Mid Qua I. & Down Qua I. & Bn value \\
\hline Iron & 0.0002 & 0.0002 & 0.0002 & 47,200 \\
Zinc & 0.0007 & 0.0007 & 0.0004 & 95 \\
Manganese & 0.0001 & 0.0001 & 0.0004 & 850 \\
Cobalt & 0.532 & 0.473 & 0.401 & 18 \\
Lead & 0.024 & 0.021 & 0.021 & 20 \\
Nickel & 0.015 & 0.017 & 0.003 & 68 \\
Copper & 0.013 & 0.002 & 0.004 & 45 \\
Chromium & 0.009 & - & - & 90 \\
Cadmium & 3.437 & 3.043 & 3.417 & 90
\end{tabular}

Table 7. Contamination degree (CD) and Pollution Load Index (PLI) of the study area.

\begin{tabular}{cccc}
\hline & Up Qua I. & Mid Qua I. & Down Qua I. \\
\hline CD & 3.437 & 3.557 & 3.847 \\
PLI & 0.0103 & 0.0134 & 0.0112 \\
\hline
\end{tabular}

Table 8. Enrichment factor from the study area.

\begin{tabular}{cccc}
\hline Parameter & Up Qua I. & Mid Qua I. & Down Qua I. \\
\hline Iron & 1 & 1 & 1 \\
Zinc & 2.458 & 3.949 & 1.608 \\
Manganese & 0.548 & 0.740 & 0.180 \\
Cobalt & 1543 & 24070 & 1704 \\
Lead & 82.09 & 115.05 & 92.74 \\
Nickel & 450.96 & 92.51 & 11.79 \\
Copper & 44.83 & 9.809 & 15.09 \\
Chromium & 32.97 & - & - \\
Cadmium & 9890 & 16,793 & 14,502 \\
\hline
\end{tabular}




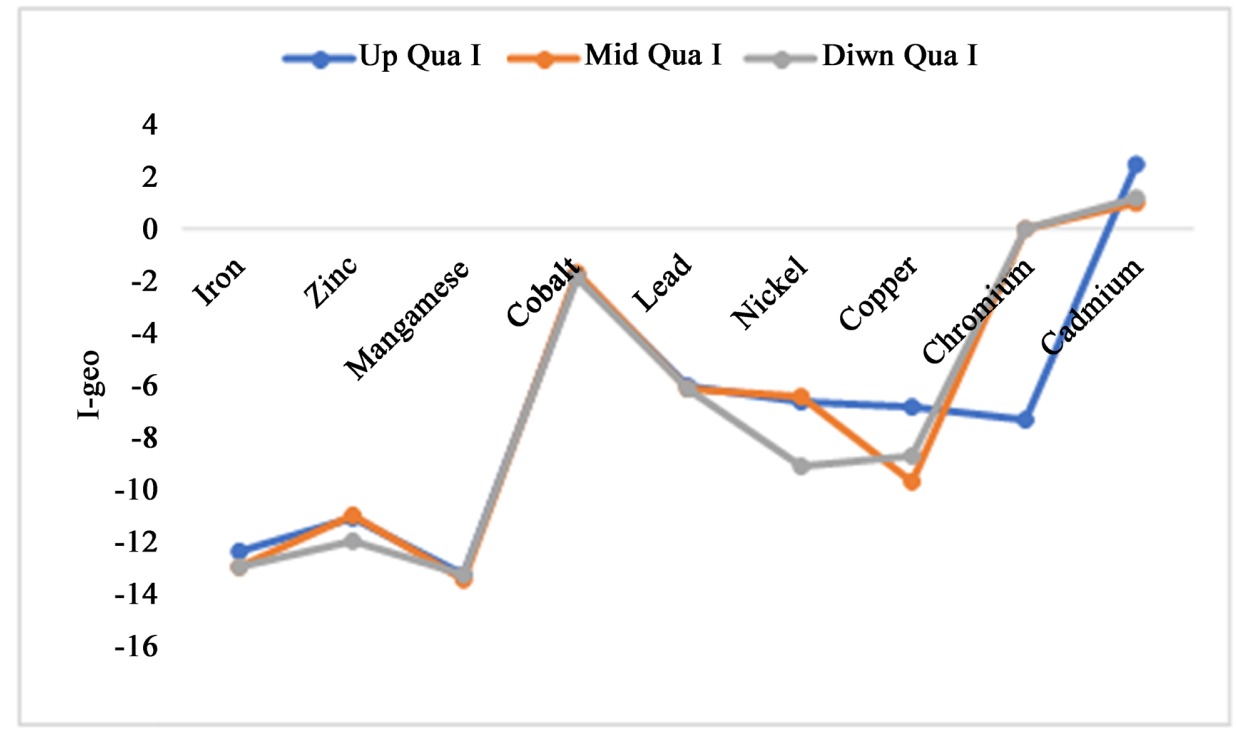

Figure 2. Distribution of heavy metals based on geo-accumulation index.
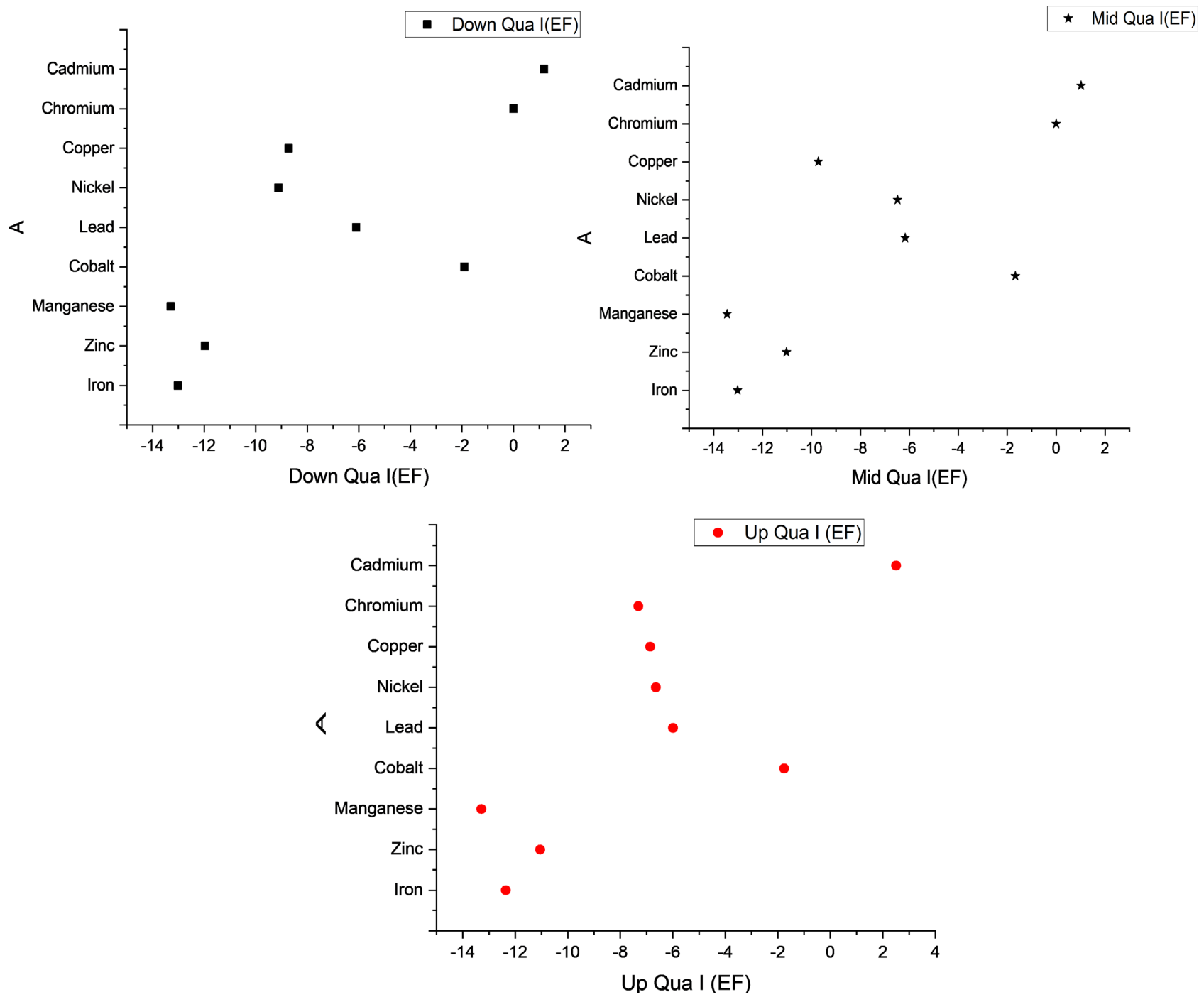

Figure 3. Enrichment Factor distribution based on sampling station. 
corroborates the results of the I-geo in terms of non-contamination of the river sediment by the predominantly selected heavy metals.

The enrichment factor (EF) was calculated using Equation (3). The results as shown in Table 8 indicate metal enrichment from the anthropogenic origin for $\mathrm{Co}, \mathrm{Ni}, \mathrm{Pb}, \mathrm{Cd}, \mathrm{Cu}$, and $\mathrm{Cr}$ in the sediment while $\mathrm{EF}$ results for $\mathrm{Fe}$ and $\mathrm{Mn}$ predicate biogenic origin. The I-geo result strongly corroborates with the EF results for Cd as shown in Figure 3, which should be of concern in the river sediment. It can be deduced that human activities as a result of the presence of many offshore crude oil facilities in the Bight of Bonny pose a serious threat to the level of cadmium in the sea bed sediment. Therefore, it is pertinent to call on the locals, agencies, and corporate bodies to be aware of the impact of anthropogenic activities on the aquatic environment of the area.

\section{Conclusion}

The use of the pollution index model has become a veritable tool in assessing the pollution level of river sediment. In the case of Bight of Bonny sea bed sediment, the I-geo results of the sea bed sediment suggest a non-polluted environment concerning some of the heavy metals studied, but $\mathrm{Cd}$ was strongly linked to the pollution of the river sediment. The EF and I-geo result strongly suggest sediment contamination by $\mathrm{Cd}$ from anthropogenic sources which are not unconnected with the oil and gas activities within the study area.

More so, heavy metals in the sediment may desorb or resuspend to cause secondary pollution of the surface water. Hence, there is a need to access the surface water pollution to evaluate the level of impact with these trace heavy metals.

\section{Conflicts of Interest}

The authors declare no conflicts of interest regarding the publication of this paper.

\section{References}

Abdullah, M. H., Sidi, J., \& Aris, A. Z. (2007). Heavy Metals (Cd, Cu, Cr, Pb, and Zn) in Meretrix Roding, Water, and Sediments from Estuaries in Sabah, North Borneo. International Journal of Environmental \& Science Education, 2, 69-74.

Adewole, S. (2018). Idoho-QIT Pipeline Replacement Project. https://ng.linkedin.com/in/adewole-solomon-mnse-coren-pmp-a02b3535

Akpan, A. W. (1991). Preliminary Investigation into the Physical Hydrology of Qua Iboe River in South Eastern Nigeria. Trans Nig Soc Biol Conserv, 113-122.

Andem, A. B., Okorafor, K. A., Oku, E. E., \& Ugwumba, A. A. (2015). Evaluation and Characterization of Trace Metals Contamination in the Surface Sediment Using Pollution Load Index (PLI) and Geo-Accumulation Index (Igeo) of Ona River, Western Nigeria. International Journal of Scientific \& Technology Research, 4, 29-34.

APHA (American Public Health Association), AWWA (American Water Works Association), \& WPCF (Water Pollution Control Federation) (1998). Standard Methods for the Examination of Water and Wastewater (20th ed.). APHA, $1325 \mathrm{p}$.

Benson, N., U., Essien, J. P., Williams, A. B., \& Ebong, G. A. (2007). Petroleum Hydrocarbons Accumulation Potential of Shellfishes from Littoral Waters of the Bight of 
Bonny, Niger Delta, Nigeria. Research Journal of Environmental Sciences, 1, 11-19. https://doi.org/10.3923/rjes.2007.11.19

Davies, O. A., \& Abowei, J. F. N. (2009). Sediment Quality of Lower Reaches of Okpoka Creek, Niger Delta, Nigeria. European Journal of Scientific Research, 26, 437-442.

Ekpo, I. E., Essien-Ibok, M. A., \& Nkwoji, J. N. (2014). Food and Feeding Habits and Condition Factor of Fish Species in Qua Iboe River Estuary, Akwa Ibom State, Southeastern Nigeria. International Journal of Fisheries and Aquatic Studies, 2, 38-46.

Eni, D. I., Arikpo, I. A., \& Oko, P. E. (2021). Evaluation of Heavy Metals and Total Hydrocarbon Concentration in the Qua Iboe River Estuary, Akwa Ibom State, Nigeria. Mediterranean Journal of Social Sciences, 12, 58-73.

Eni, I. D., Arikpo, I. A., \& Oko, P. E. (2021). Evaluation of Heavy Metals and Total Hydrocarbon Concentration in the Qua Iboe River Estuary, Akwa Ibom State, Nigeria. Mediterranean Journal of Social Sciences, 12, 58-73. https://doi.org/10.36941/mjss-2021-0012

Esu, E. O., \& Amah, E. A (1999). Physicochemical and Bacteriological Quality of Natural Waters in Parts of Akwa Ibom and Cross River States, Nigeria. Global Journal of Pure and Applied Sciences, 5, 525-534.

Fernandes, L. L., \& Nayak, G. N. (2012). Geochemical Assessment in a Creek Environment in Mumbai, West Coast of India. Environmental Forensics 13, 45-54. https://doi.org/10.1080/15275922.2011.643340

Ghrefat, H., Abu Rukah, Y., \& Rosen, M. A. (2011). Application of Geoaccumulation Index and Enrichment Factor for Assessing Metal Contamination in the Sediments of Kafrain Dam, Jordan. Environmental Monitoring and Assessment, 178, 95-109. https://doi.org/10.1007/s10661-010-1675-1

Harikumar, P. S., Nasir, U. P., \& Mujeebu Rahman, M. P. (2009). Distribution of Heavy Metals in the Core Sediments of a Tropical Wetland System. International Journal of Environmental Science \& Technology, 6, 225-232. https://doi.org/10.1007/BF03327626

Iloeje, N. P. (1991). A New Geography of Nigeria. Longman Nigeria Ltd.

Iwuoha, G.N., Osuji, L.C., \& Horsfall, M. J. (2012). Index Model Analysis Approach to Heavy Metal Pollution Assessment in Sediments of Nworie and Otamiri Rivers in Imo State of Nigeria. Research Journal of Chemical Sciences, 2, 1-8.

Ji, Y., Feng, Y., Wu, J., Zhu, T., Bai, Z., \& Duan, C. (2008). Using the Geoaccumulation Index to Study Source of Profiles of Soil Dust in China. Journal of Environmental Sciences, 20, 571-578. https://doi.org/10.1016/S1001-0742(08)62096-3

Jordanova, M., Hristovski, S., Musai, M., Boskovska, V., Rebok, K., DinevskaKovkarovska, S., \& Melovski, L. (2018). Accumulation of Heavy Metals in Some Organs in Barbel and Chub from Crn Drim River in the Republic of Macedonia. Bulletin of Environmental Contamination and Toxicology, 101, 392-397.

https://doi.org/10.1007/s00128-018-2409-2

Liu, M., Zhong, J., Zheng, X., Yu, J., Liu, D., \& Fan, C. (2018). Fraction Distribution and Leaching Behavior of Heavy Metals in Dredged Sediment Disposal Sites around Meiliang Bay, Lake Taihu (China). Environmental Science and Pollution Research, 25, 9737-9744. https://doi.org/10.1007/s11356-018-1249-2

Loska, K., Cebula, J., Pelczar, J., Wiechula, D., \& Kwapulinski, J. (1997). Use of Enrichment, and Contamination Factors Together with Geoaccumulation Indices to Evaluate the Content of $\mathrm{Cd}, \mathrm{Cu}$, and $\mathrm{Ni}$ in the Rybnik Water Reservoir in Poland. Water, Air, and Soil Pollution, 93, 347-365. https://doi.org/10.1007/BF02404766

Marchand, C., Lalliet, V. E., Baltzer, F., Alberic, P., Cossa, D., \& Baillif, P. (2006). Heavy Metals Distribution in Mangrove Sediments along the Mobile Coastline of French Guiana. Marine Chemistry, 98, 1-17. https://doi.org/10.1016/j.marchem.2005.06.001 
Muller, G. (1969). Index of Geoaccumulation in Sediments of the Rhine River. GeoJournal, 2, 108-118.

Ntekim, E., Ekwere, S., \& Ukpong, E. (1993). Heavy Metal Distribution in Sediments from Calabar River, Southeastern Nigeria. Environmental Geology, 21, 237-241. https://doi.org/10.1007/BF00775913

Nur, A. S., Ahmad, Z. A., Mohamad, P. Z., Hazzeman, H., Wan, Y. L., \& Noorain, M. I. (2013). Application of Geoaccumulation Index and Enrichment Factors on the Assessment of Heavy Metal Pollution in the Sediments. Journal of Environmental Science and Health, Part A: Toxic/Hazardous Substances and Environmental Engineering, 48, 182-190. https://doi.org/10.1080/10934529.2012.717810

Ogbeibu, A. E., Omoigberale, M. O., Ezenwa, I., Eziza, J. O., \& Igwe, J. O. (2014). Using Pollution Load Index and Geoaccumulation Index for the Assessment of Heavy Metal Pollution and Sediment Quality of the Benin River, Nigeria. Natural Environment, 2, 1-9.

Oguzie, F. A. (2003). Heavy Metals in Fish, Water and Effluents of Lower Ikpoba River in Benin, Nigeria. Pakistan Journal of Science and Industrial Research, 46, 156-160.

Oze, G., Oze, R., Anunuso, C., Ogukwe, C., Nwanjo, H., \& Okorie, K. (2005). Heavy Metal Pollution of Fish of Qualboe River Estuary: Possible Implications for Neurotoxicity. The Internet Journal of Toxicology, 3.

Praveena, S. M., Ahmed, A., Radojevic, M., Abdullah, M. H., \& Aris, A. Z. (2008). Multivariate and Geoaccumulation Index Evaluation in Mangrove Surface Sediment of Mengkabong Lagoon, Sabah. Bulletin of Environmental Contamination and Toxicology, 81, 52-56. https://doi.org/10.1007/s00128-008-9460-3

Reimann, C., \& De Caritat, P. (2004). Distinguishing between Natural and Anthropogenic Sources for Elements in the Environment: Regional Geochemical Surveys versus Enrichment Factors. Science of the Total Environment, 337, 91-107.

https://doi.org/10.1016/j.scitotenv.2004.06.011

Shyleshchandran, M. N., Mohan, M., \& Ramasamy, E. V. (2018). Risk Assessment of Heavy Metals in Vembanad Lake Sediments (South-West Coast of India), Based on Acid-Volatile Sulfide (AVS)-Simultaneously Extracted Metal (SEM) Approach. Environmental Science and Pollution Research, 25, 7333-7345. https://doi.org/10.1007/s11356-017-0997-8

Sutherland, R. A. (2000). Bed Sediment-Associated Trace Metals in an Urban Stream, Oahu, Hawaii. Environmental Geology, 39, 611-627. https://doi.org/10.1007/s002540050473

Tomlinson, D. L., Wilson, J. G., \& Harris, C. R. (1980). Problems in the Assessment of Heavy-Metal Levels in Estuaries and the Formation of a Pollution Index. Helgoländer Meeresuntersuchungen, 33, 566-575. https://doi.org/10.1007/BF02414780.

Turekian, K. K., \& Wedepohl, K. H. (1961). Distribution of the Elements in Some Major Units of the Earth's Crust. Geological Society of America Bulletin, 72, 175-192.

Uwah, I. E., Dan, S. F., Etiuma, R. A., \& Umoh, U. E. (2013). Evaluation of Status of Heavy Metals Pollution of Sediments in Qua-Iboe River Estuary and Associated Creeks, SouthEastern Nigeria. Environment and Pollution, 2, 110-122.

Zhang, C., Yu, Z. G., Zeng, G. M., Jiang, M., Yang, Z. Z., Cui, F., Zhu, M. Y., Shen, L. Q., \& Hu, L. (2014). Effects of Sediment Geochemical Properties on Heavy Metal Bioavailability. Environment International, 73, 270-281.

https://doi.org/10.1016/j.envint.2014.08.010

Zhang, J., \& Liu, C. L. (2002). Riverine Composition and Estuarine Geochemistry of Particulate Metals in China-Weathering Features, Anthropogenic Impact and Chemical Fluxes. Estuarine, Coastal and Shelf Science, 54, 1051-1070.

https://doi.org/10.1006/ecss.2001.0879 